Article

\title{
Toward Sustainability in Rural Areas: Composting Palm Tree Residues in Rotating Bioreactors
}

\author{
Fahad Alkoaik *, Abdulelah Al-Faraj, Ibrahim Al-Helal, Ronnel Fulleros, Mansour Ibrahim \\ and Ahmed M. Abdel-Ghany *(1)
}

Department of Agricultural Engineering, King Saud University, Riyadh 11451, Saudi Arabia; faraj@ksu.edu.sa (A.A.-F.); imhelal@ksu.edu.sa (I.A.-H.); rfulleros@ksu.edu.sa (R.F.); malsamee@ksu.edu.sa (M.I.)

* Correspondence: falkoaik@ksu.edu.sa (F.A.); aghany@ksu.edu.sa (A.M.A.-G.)

Received: 23 November 2019; Accepted: 23 December 2019; Published: 25 December 2019

\begin{abstract}
Huge quantities of palm tree residues are available annually in Saudi Arabia; they are often disposed of by burning, leading to large environmental pollution and health problems. Enclosed composting may be a successful method for utilizing these residues. Effective composting in a rotary bioreactor depends on the composting materials and the frequencies of the rotation-aeration process. Here, we attempted to determine the optimal method for composting these residues in a bioreactor. Four identical pilot-scale bioreactors (D1-D4) were used. The respective aeration-rotation frequencies were continuous (D1), and $20 \mathrm{~min}$ per $1 \mathrm{~h}$ (D2), $2 \mathrm{~h}$ (D3), and $3 \mathrm{~h}$ (D4); the rotation speed of the bioreactors was $3 \mathrm{rpm}$. Three periods were analyzed; their names and their respective lengths for D1, D2, D3, and D4 were as follows: the lag period was $10 \mathrm{~h}$ for each, the mesophilic periods were 13,14 , 89 , and $231 \mathrm{~h}$, and the thermophilic periods were $0,55,71$, and $17 \mathrm{~h}$. The peak compost temperatures $\left(T_{c, \max }\right)$ for D1, D2, and D3 were $65.2,57.2$, and $46.9^{\circ} \mathrm{C}$, and were achieved at 36,71 , and $108 \mathrm{~h}$ of operation, respectively. In D1, $T_{\mathrm{c}}$ quickly declined after reaching $T_{\mathrm{c}, \max }$ due to limited microbial activity at $T_{\mathrm{c}}>60^{\circ} \mathrm{C}$. In D2, a $T_{\mathrm{c}}$ of $50-57.2^{\circ} \mathrm{C}$ was maintained for $61 \mathrm{~h}$, and the highest organic matter degradation (OMD) of 0.30 was achieved. During the composting period, the carbon to nitrogen $(C / N)$ ratio and moisture contents $(M C)$ remained in the optimal ranges for microorganisms and did not affect the composting process. The results indicated that combined aeration-rotation for 20 min every hour (D2) gave the best results for composting palm tree residues, it ensured the hygiene safety of the end product, and it also consumed less power for aeration and rotation than D1.
\end{abstract}

Keywords: aeration; bioreactor; compost; palm tree residues; rotation; rural area

\section{Introduction}

Date palm (Phoenix dactylifera L.) retains a distinguished position in many countries in the world, particularly in the Middle East area and in the Arabian Peninsula. According to recent reports and literature, there are more than 120 million date palm trees distributed worldwide. From this number of palm trees, the Middle East and North Africa countries estimated to have more than $70 \%-90 \%$ of the share [1]. In Saudi Arabia, the number of date palm trees is increasing gradually, reaching more than 28 million in 2018 [2]. Each palm tree usually produces about $25-35 \mathrm{~kg}$ of waste residues per year; consequently, more than 900 thousand tons of dry residues are expected to be produced in Saudi Arabia each year [3,4]. These residues are often disposed of by burning, leading to large environmental pollution and health problems [5]. Palm residues (fronds, rachis, spines, leaflets, clusters, and fibers) are considered as a sustainable source of organic matter [6,7]. These residues can be composted and used in the soil as growth media to improve the soil structure by increasing the organic matter of soil, thus improving the poor soil fertility in the desert of Saudi Arabia [8-10]. Enclosed composting 
systems (rotary bioreactors) have proven to be an efficient technique in farm-scale composting or small projects, and are the most suitable composting systems to be used successfully in the Arabian Peninsula [11]. This is because of the dry climate, high daily water evaporation rate, and water shortage [12]. Enclosed bioreactors are able to process large amounts of organic waste in a limited space; in addition, any type of waste, such as meat, animal and chicken manure, bio-solids, food scraps, ... etc., can be accommodated effectively. Enclosed rotary bioreactors provide good mixing, and enhance the uniformity of temperature distribution within the composted material. These bioreactors produce quick, consistent, and uniform composted materials without any related problems of odor or leachate [13-18]. Moreover, good control of operational and environmental affecting factors (i.e., compost temperature, moisture content, and airflow rate) can be achieved [13]. Rotary bioreactors can produce compost in just a few weeks or even a few days, are more efficient at material breakdown, decrease unpleasant odors, prevent disease transmission, and need only small amounts of carbon source materials such as shavings or poultry litters to be added [19]. In bioreactor composting systems, the aerobic composting depends mainly on the aeration and rotation frequencies as the most critical parameters affecting the composting process. Excessive or insufficient aeration can negatively affect the decomposition process. Thus, for effective composting, it is essential to adjust the aeration and rotation frequencies at the appropriate levels for the composted materials [13]. Research studies have reported that oxygen is consumed within two hours, after which the reaction becomes anaerobic and inefficient [20-23]. In general, the efficiency of composting depends on the physical and chemical properties of the compost raw materials and the operation conditions of the composting system. Combining rotating and aerating processes provides the most suitable environment with sufficient amount of oxygen and sufficient bio-availability of organic material that makes the aerobic microbes quickly decompose the waste material [18]. However, in the previous literature, few studies have used and evaluated the continuous or the intermittent combined rotation-aeration for enclosed bioreactors. For example, in a pilot-scale test using rotary drum bioreactors to compost vegetable wastes, the drums were manually turned for three rotations at four different intervals $(6,12,18$, and $24 \mathrm{~h})$ [14]. Twenty-four-hour intervals were found to give the best composting performance as well as stable compost [14]. Subsequently, research groups have investigated the number of rotations in a $24 \mathrm{~h}$ period: one rotation [15], two rotations [17], three rotations [18], and four rotations [16]. In these studies, the composting materials were vegetable wastes and tree leaves. Aerobic conditions were maintained naturally by opening side doors in the drums half-way after the rotations were completed [14-18]. Continuous aeration-rotation was used for composting tomato plant residues mixed with chicken manure in a pilot-scale bioreactor with the aim of reducing the active phase period [11] and analyzing energy performance [24].

A literature survey of previous studies revealed that (i) studies on mechanically operated, intermittent aeration-rotation are very limited [11], (ii) composting in a rotating bioreactor depends mainly on the composted material and the combined aeration-rotation frequency, (iii) the impact of the combined aeration-rotation frequencies on the bioreactor performance and the composting process is still unclear, and (iv) studies on composting palm tree residues in a closed system or even in an open system (e.g., static pile, windrows) are not available. On the other hand, successful and effective composting requires a sufficient amount of oxygen via aeration, and requires adjusting control parameters such as the temperature of composting, the mixture moisture content $(M C)$, and the carbon to nitrogen $(C / N)$ ratio [25]. Because an operational method for composting palm tree residues is not available yet, providing such method is necessary to develop our rural areas toward sustainable life. This technique can help farmers to dispose of palm trees or any other agricultural residues in a useful and environmentally responsible way.

Therefore, this study aimed to determine the optimal operational method for composting palm trees residues in a rotary drum bioreactor. Four strategies were suggested and evaluated: continuous aeration-rotation (D1), and $20 \mathrm{~min}$ aeration-rotation every $1 \mathrm{~h}$ (D2), $2 \mathrm{~h}$ (D3), and $3 \mathrm{~h}$ (D4). We evaluated (i) the degree of uniformity of the compost temperature during the active phase of composting, (ii) the 
evolution of compost temperatures including lag, mesophilic, and thermophilic periods (temperature and duration), and (iii) the organic matter degradation rate (OMD). However, the evaluation of the stability and maturity of compost (i.e., during the curing phase outside the bioreactor) is beyond the scope of the current study.

\section{Materials and Methods}

\subsection{Determining the Compost Parameters}

Moisture content $(M C, \%)$, dry weight $(D w)$, volatile solids (organic matter, $O M$ as $\% D w)$ and ash were measured according to procedures of American Society for Testing and Materials (ASTMInternational) (D3173-73) [26]. Representative compost samples were placed in an air oven at $105^{\circ} \mathrm{C}$ for $24 \mathrm{~h}$ until constant weights were achieved to determine the $M C$. OM was estimated by placing the dried sample in a muffle furnace for $2 \mathrm{~h}$ at $550{ }^{\circ} \mathrm{C}$. The ash was weighed; $O M$ was determined by subtracting ash weight from dry weight. The content (\%) of the total organic carbon (TOC) was calculated according to Haug [27], by assuming that it was equal to $55 \%$ of the organic matter $(O M)$ as follows:

$$
\begin{aligned}
O M(\%) & =100-A \operatorname{sh}(\%), \\
\operatorname{TOC}(\%) & =O M(\%) \times 0.55
\end{aligned}
$$

The organic matter degradation $(O M D)$, or the fraction of the $O M$ that was degraded, for the compost material was calculated according to [27] as:

$$
O M D=1-\frac{\left(100-O M_{i}\right)}{\left(100-O M_{f}\right)}
$$

where $O M_{i}$ and $O M_{f}$ are the initial (at day 0) and final (at day 9) organic matter (\%), respectively.

Total nitrogen (TN, \%) was analyzed based on the Total Kjeldahl-N (TKN) using a Foss-Kjeltec analyzer (Model: 8100, Denmark). The TKN analyzes the summation of organic nitrogen, nitrogen in the forms of ammonia (NH3-N) and ammonium (NH4-N), which are suitable microbial nitrogen forms during the active phase of composting [28,29]. Consequently, the carbon to nitrogen ratio $(C / N)$ was calculated using the values of $T O C$ and $T N$. The $M C$ and $C / N$ ratios were estimated at the beginning (day 0 ) and end (day 9) of the composting experiment.

\subsection{Initial Mixture Design}

The primary substrate used in the study (as a carbon source) was palm tree residues. These residues were collected, at 9\% MC, from Al-Deraya County in the Riyadh area, Saudi Arabia. The collected residues were crushed using a FYS-76-shredder (Mainland, Zhejiang, China). Grinding was accomplished to decrease the particle size of residues up to $1-2 \mathrm{~cm}$ to stimulate better aeration and $M C$ uniform distribution and to enhance the microbial degradation process. Chicken manure was used as an amendment (i.e., the nearby available nitrogen source) to correct the $C / N$ ratio. The chicken manure, at $6.2 \% M C$, was collected from a broiler chicken farm in the Riyadh area. Calculations were made to create a compost mixture (i.e., crushed palm tree residues, chicken manure, and water) that has the optimum level of $\mathrm{MC}(60 \%)$ and a $C / N$ ratio of 30:1; this was performed by solving Equations (4) and (5) simultaneously [27]. Figure 1 shows the procedure of the experimental steps including the design of the initial compost mixture.

$$
\begin{gathered}
M C(\%)=\frac{\left(M C_{c} Q_{c}+M C_{r} Q_{r}\right)}{\left(Q_{c}+Q_{r}\right)} \\
(C / N)=\frac{\left\{Q_{c} C_{c}\left(100-M C_{c}\right)+Q_{r} C_{r}\left(100-M C_{r}\right\}\right.}{\left\{Q_{c} N_{c}\left(100-M C_{c}\right)+Q_{r} N_{r}\left(100-M C_{r}\right\}\right.}
\end{gathered}
$$


where $M C_{c}, M C_{r}, Q_{c}, Q_{r}, C_{c}, C_{r}, N_{c}$, and $N_{r}$ are the moisture contents (\%), mass (kg), carbon content $(\%)$, and nitrogen content (\%) of the chicken manure (subscript c) and palm tree residues (subscript $\mathrm{r}$ ), respectively. An Excel spread sheet was used to calculate the proportion of each substrate required to meet the optimum $C / N$ ratio (30:1) and $M C(60 \%)$. The determined proportion of each consequent was validated by recalculating the $C / N$ ratio and $M C$ of the initial mixture (Table 1 ).

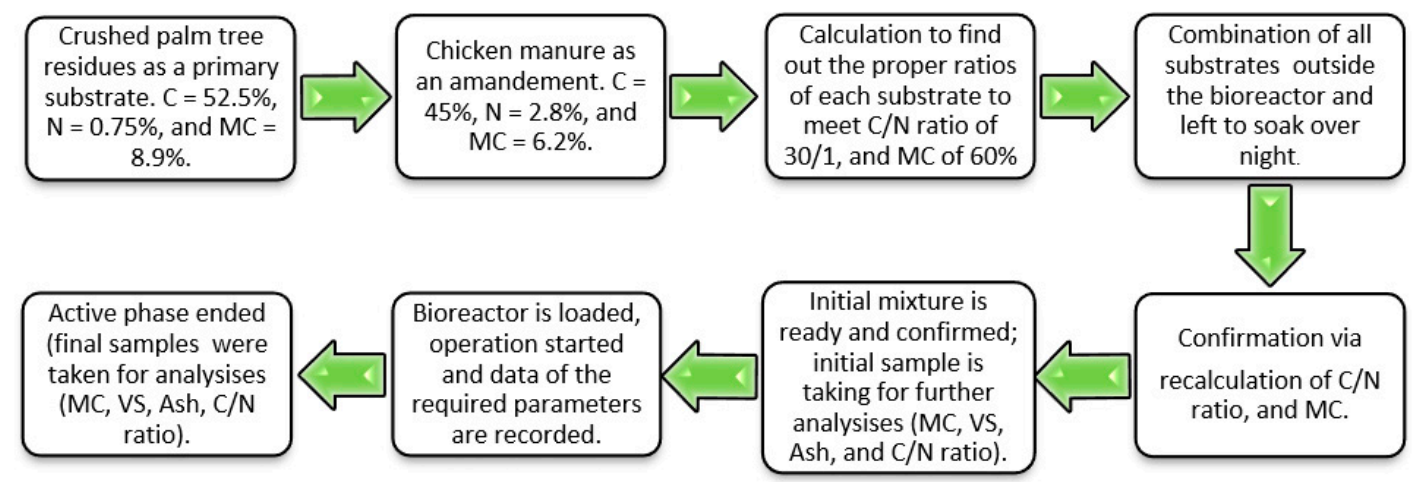

Figure 1. Diagram showing the procedure of composting experiment from start to end. MC: moisture content; VS: volatile solids.

Table 1. Results of the initial mixture calculation and confirmation.

\begin{tabular}{|c|c|c|c|c|c|}
\hline Material & $\begin{array}{c}M C(\%) \\
(\%)\end{array}$ & $\begin{array}{c}C(\%) \\
(\%)\end{array}$ & $\begin{array}{c}N(\%) \\
(\%)\end{array}$ & $\begin{array}{c}C / N \\
\text { (Ratio) }\end{array}$ & $\begin{array}{c}Q(\mathrm{~kg}) \\
(\mathrm{kg})\end{array}$ \\
\hline Crushed residues & 8.85 & 52.5 & 0.75 & $70: 1$ & 12.5 \\
\hline Chicken manure & 6.15 & 45.0 & 2.8 & $16: 1$ & 9.3 \\
\hline Water & 100 & - & - & - & 28.6 \\
\hline Total & & & & & 50.4 \\
\hline \multicolumn{6}{|c|}{ Confirmation } \\
\hline \multicolumn{2}{|c|}{$C / N$ ratio after mixing } & \multicolumn{4}{|c|}{$29: 1$} \\
\hline \multicolumn{2}{|c|}{ Initial $M C$ of mixture (\%) } & \multicolumn{4}{|c|}{60} \\
\hline
\end{tabular}

\subsection{Bioreactor Composting Systems}

Four identical pilot-scale, rotary-drum bioreactors, each with a volume of $0.2 \mathrm{~m}^{3}$ (Figure 2a), were designed and constructed in the laboratory at the educational farm, Agricultural Engineering Department, King Saud University, (Riyadh, Saudi Arabia, $46^{\circ} 47^{\prime}$ E, longitude and $24^{\circ} 39^{\prime}$ N, latitude). To reduce the heat loss and enhance metabolic exothermic reactions, the outer surfaces of the bioreactors were insulated with glass wool $(25 \mathrm{~mm}$ thick). Each bioreactor was rotated around its axis (i.e., fixed tube, $50 \mathrm{~mm}$ outer diameter) at $3 \mathrm{rpm}$. The fixed tube was used for aeration and to support the temperature sensors (Figure 2b). A detailed description of the bioreactors was reported in [11,24]. To optimize the efficient operational method for composting palm tree residues, one bioreactor was operated continuously (continuous aeration-rotation, D1), and three were operated for $20 \mathrm{~min}$ of aeration-rotation at 1, 2, and 3-hour intervals (D2, D3, and D4), respectively. A control unit was implemented in each bioreactor to adjust the on-off operation frequencies. A layout dimension for the constructed rotary-drum bioreactor, installed on steel-angle frames with the rotating system, is illustrated in Figure 2a (dimensions are in $\mathrm{cm}$, not to scale). 

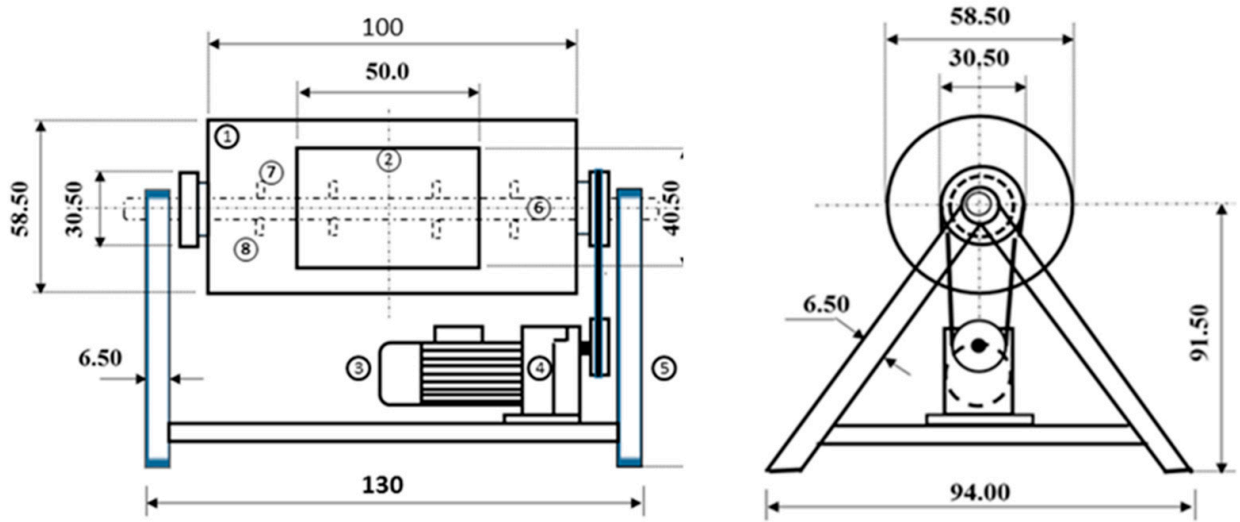

(1)Bioreactors (2) Opening doors (3)Electric motor (4) Gearbox (5)Steel frames (6)Fixed tubes (7)Aeration ports (8)Thermocouple holders

(a)

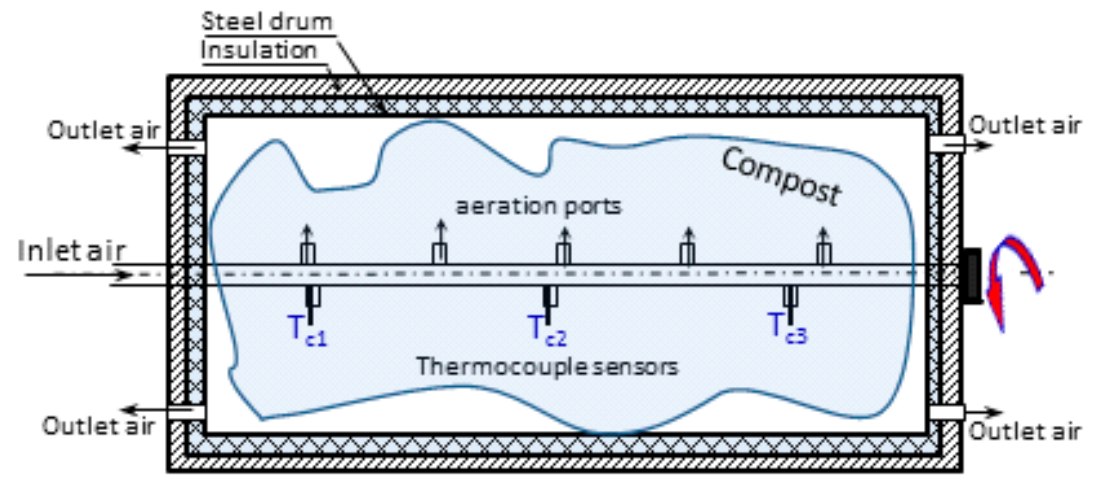

(b)

Figure 2. (a) Schematic diagram showing the constructed rotary-drum bioreactor system, (dimensions are in $\mathrm{cm}$, not to scale); (b) cross-sectional view of the bioreactor drum showing the inlet and outlet aeration ports and the locations of thermocouple sensors.

\subsection{Experimental Procedure and Temperature Measurements}

A similar experimental procedure was reported in [11,24]. For each bioreactor, compressed air (flow rate of $0.005 \mathrm{~m}^{3} \mathrm{~min}^{-1}$ at 10-bar) was supplied to the horizontal tube which the bioreactor rotates around it. The compressed air passed from the reservoir to the compost materials via holes that were made in the horizontal tube (Figure 2b); a pressure regulator was used to adjust the proper airflow rate. In each bioreactor, the compost temperatures $\left(T_{\mathrm{c} 1}, T_{\mathrm{c} 2}\right.$, and $\left.T_{\mathrm{c} 3}\right)$ were measured by using three copper-constantan thermocouples (type-T, Cole Parmer, Chicago, IL, USA) fixed longitudinally at three locations on the opposite side of the aeration holes; this to minimize the effect of the inlet air on the temperature measurements, and $T_{\mathrm{c}}$ was estimated as the average value of $T_{\mathrm{c} 1}, T_{\mathrm{c} 2}$, and $T_{\mathrm{c} 3}$ (Figure 2b). The thermocouple wires passed inside the tube to the outside and were connected to a portable data logger (Model: Testo 177-T4 V01-02). Ambient air temperature $\left(T_{\mathrm{am}}\right)$ was measured with a Thermo-Hygrometer DMA033 (LSI-Lastem, Milano, Italy). The measured parameters were recorded every 10 seconds, averaged for every $10 \mathrm{~min}$ period and saved in the data logger. In order to reach the steady-state operation conditions, to ensure the accuracy of the measuring devices and to ensure that the measured parameters were in the correct ranges and logical trends, preliminary experiments were conducted for composting the prepared mixture (i.e., moist crushed palm tree residues and chicken manure). After that, the actual experiment was conducted. 


\section{Results and Discussion}

\subsection{Composting Phases and Temperatures}

Composting is a chemical exothermic process which generates heat due to aerobic metabolic reactions in the composting materials. During the active phase of composting, the compost temperature $\left(T_{\mathrm{c}}\right)$, acid production, $\mathrm{O}_{2}, \mathrm{CO}_{2}, \mathrm{pH}$, etc. are often used as indirect measures of microbial activities. In general, compost microorganisms grow within a wide range of $\mathrm{pH}$ (5-9); in this study, only the initial and final $\mathrm{pH}$ were measured on day 0 and day 9 (i.e., the end of active phase) and they were 7.3 and 8.8, respectively. However, the evolution of the compost temperature $\left(T_{\mathrm{c}}\right)$ as an overall and more representative indicator of microbial activities was monitored during the composting process. The generated heat increases the temperature of the composted material and bioreactor elements. Rotating bioreactors induce the mixing of compost materials and create, to some extent, nearly uniform temperatures within the composted mixture. Therefore, as illustrated in Figure 3, small differences (up to $3{ }^{\circ} \mathrm{C}$, max) were recorded among the three temperatures of compost $\left(T_{\mathrm{c} 1}, T_{\mathrm{c} 2}\right.$, and $\left.T_{\mathrm{c} 3}\right)$ measured in the four bioreactors (D1, D2, D3, and D4, Figure 3). In the discussion below, the mean value of the three compost temperatures $\left(T_{\mathrm{c} 1}, T_{\mathrm{c} 2}\right.$, and $\left.T_{\mathrm{c} 3}\right)$ was used to represent the average compost temperature $\left(T_{\mathrm{c}}\right)$ in each bioreactor.

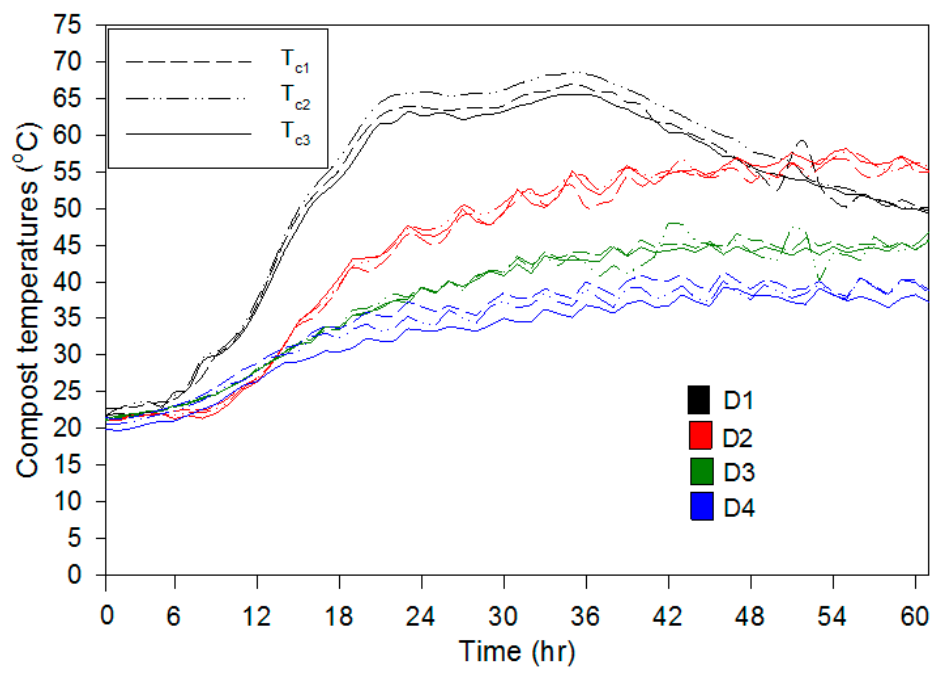

Figure 3. The time course of the compost temperatures recorded by the three thermocouple sensors $\left(T_{\mathrm{c} 1}, T_{\mathrm{c} 2}\right.$, and $\left.T_{\mathrm{c} 3}\right)$ fixed at three different locations inside each one of the four bioreactors (D1, D2, D3, and D4).

The composting process exhibited three distinguishable periods: the lag period, active period and maturation (curing period). The lag period begins when the composting process starts; it is a period of microbial adaptation. After microbes have adapted to the new environment, they begin to proliferate by using sugars, starches, simple celluloses, and amino acids present in the composted material. Due to the accelerating microbial activity, the compost temperature $\left(T_{\mathrm{c}}\right)$ increases. In the transition from the lag to active period, the compost temperature $\left(T_{c}\right)$ increases rapidly until the biodegradable organic matter is utilized easily $[27,30]$. The time courses of the measured compost and ambient air temperatures $\left(T_{\mathrm{c}}\right.$ and $\left.T_{\mathrm{am}}\right)$ in the four bioreactors are illustrated in Figure 4. In general, clear and different patterns of $T_{\mathrm{C}}$ behaviors were observed among the different composting treatments (D1-D4). A lag period of $10 \mathrm{~h}$ was recorded in each of the four treatments. The fast breakdown of the available organic matter $(O M)$ and nitrogenous compounds throughout the microbial activities causes $T_{\mathrm{c}}$ to increase to the mesophilic phase $\left(T_{\mathrm{am}} \leq T_{\mathrm{c}}<45^{\circ} \mathrm{C}\right)$. This behavior lasted for 13, 14, 89, and $231 \mathrm{~h}$ in treatments D1, D2, D3, and D4, respectively; this depended mainly on the aeration-rotation frequency and the composted material. $T_{\mathrm{C}}$ continued to increase to the thermophilic phase $\left(T_{\mathrm{C}}>45^{\circ} \mathrm{C}\right)$ only in 
D1, D2, and D3 and lasted for 55, 71, and $17 \mathrm{~h}$, respectively. Peak values of the compost temperature $\left(T_{c, \max }\right)$ were recorded as $65.2,57.2$, and $46.9^{\circ} \mathrm{C}$ after 36,71 and $108 \mathrm{~h}$ in D1, D2, and D3, respectively; however, D4 never reached the thermophilic stage. Accordingly, $20 \mathrm{~min}$ aeration-rotation every $3 \mathrm{~h}$ is not recommended for composting palm tree residues. Table 2 summarizes the period of each stage during the composting process, the maximum temperature of compost, and the corresponding time reached in the four bioreactors.

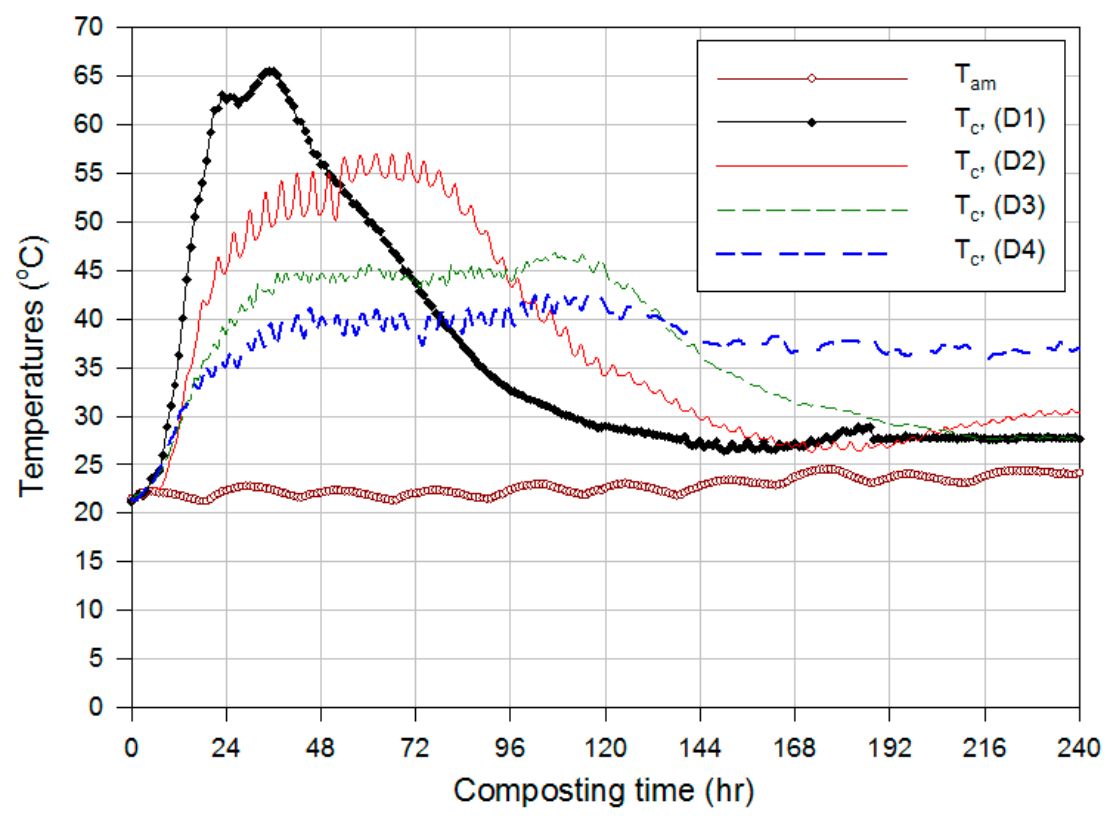

Figure 4. The time course of the average compost temperatures $\left(T_{\mathrm{c}}\right)$ measured in the four bioreactors (D1, D2, D3, and D4), and that of the ambient air $\left(T_{\mathrm{am}}\right)$ during the composting process.

Table 2. Periods of the different stages of the composting process recorded for the four operation methods in the four bioreactors.

\begin{tabular}{|c|c|c|c|c|c|c|}
\hline Treatment & $\begin{array}{c}\text { Aeration/Rotation } \\
\text { Method }\end{array}$ & $\begin{array}{c}\text { Lag Period }{ }^{1} \\
\text { (h) }\end{array}$ & $\begin{array}{l}\text { Mesophilic } \\
\text { Period }^{2} \text { (h) }\end{array}$ & $\begin{array}{c}\text { Thermal } \\
\text { Period }^{3}(h)\end{array}$ & $\begin{array}{c}T_{\mathrm{c}, \max } \\
\left({ }^{\circ} \mathrm{C}\right)\end{array}$ & $\begin{array}{c}\text { Peak Time } \\
\text { (h) }\end{array}$ \\
\hline D1 & Continuous & 10 & 13 & 55 & 65.2 & 36 \\
\hline D2 & $20 \mathrm{~min}$ every $1 \mathrm{~h}$ & 10 & 14 & 71 & 57.2 & 71 \\
\hline D3 & 20 min every $2 \mathrm{~h}$ & 10 & 89 & 17 & 46.9 & 108 \\
\hline D4 & 20 min every $3 \mathrm{~h}$ & 10 & 231 & 0 & 43 & 110 \\
\hline
\end{tabular}

In bioreactor D1, organic matter degradation was clearly reduced after the compost temperature $\left(T_{\mathrm{c}}\right)$ exceeded $65^{\circ} \mathrm{C}$ due to the limitation of microbial activities. Hence, high levels of $T_{\mathrm{c}}$ may have surpassed the optimum conditions for the thermophilic microorganisms; consequently, microbial growth quickly declined, resulting in $T_{\mathrm{c}}$ decreasing. Moreover, the continuous aeration in the D1 treatment increased the total nitrogen loss in the form of ammonia $\left(\mathrm{NH}_{3}\right)$ emissions as affected by the high aeration rate, high temperature, and continuous mixing of compost. Therefore, the continuous aeration-rotation method (D1) is not recommended for composting palm tree residues. The compost temperature $\left(T_{\mathrm{C}}\right)$ increased to the thermophilic stage in bioreactors D2 and D3, and $T_{\mathrm{c}}$ did not exceed $65^{\circ} \mathrm{C}$. However, a $T_{\mathrm{c}}$ of $50-57^{\circ} \mathrm{C}$ was recorded only in D2, where it lasted for 61 hours. This is sufficient to ensure the hygiene safety of the end product according to the recommendations of the Canadian Council of Ministers of the Environment Guidelines for a compost free of pathogens and weed seeds [31]. Accordingly, the operation method of D2 is strongly recommended for composting palm tree residues. 


\subsection{Organic Matter Decomposition (OMD)}

Estimates of the degradation of organic matter $(O M D)$, as an indicator of microbial activity, during the active phase of composting in the four bioreactors (D1-D4) are shown in Table 3. Initially, the organic matter contents were similar in all treatments; then, they decreased as the decomposition progressed. The highest $O M D$ of 0.30 was recorded in treatment D2 (20 min of aeration/rotation every $1 \mathrm{~h}$ ), which is somewhat lower than the value of 0.37 reported in [32]. This can be explained by the fact that the active composting period in the present study lasted almost 6 days compared to the 15 days reported in [32]. Moreover, during the active phase of composting, the degradation of easily degradable compounds (soluble compounds of low molecular weight) under aerobic conditions takes place, while lignocellulosic materials (the available organic matter is low) such as palm tree residues continue to decompose during the curing phase. Therefore, the low OMD in treatment D2 during the active phase was due to the nature of palm tree residues (high lignin). These results emphasize that the D2 method is recommended for composting palm tree residues effectively.

Table 3. Compost parameters estimated at day 0 and day 9 for the four bioreactor treatments (D1-D4). OM: organic matter content; OMD: organic matter degradation.

\begin{tabular}{|c|c|c|c|c|c|c|c|c|}
\hline Treatment & $\begin{array}{c}\text { Aeration/Rotation } \\
\text { Method }\end{array}$ & $\begin{array}{l}\text { Stage } \\
\text { (Day) }\end{array}$ & MC (\%) & OM (\%) & C (\%) & N (\%) & $\mathrm{C} / \mathrm{N}$ & OMD \\
\hline \multirow{2}{*}{ D1 } & \multirow{2}{*}{ Continuous } & 0 & 60.45 & 69.52 & 43.42 & 1.57 & $27.7: 1$ & \multirow{2}{*}{0.24} \\
\hline & & 9 & 54.18 & 59.81 & 34.77 & 1.70 & $20.5: 1$ & \\
\hline \multirow{2}{*}{ D2 } & \multirow{2}{*}{$20 \mathrm{~min}$ every $1 \mathrm{~h}$} & 0 & 59.90 & 69.80 & 43.58 & 1.57 & $27.8: 1$ & \multirow{2}{*}{0.30} \\
\hline & & 9 & 53.37 & 56.89 & 33.08 & 1.77 & $18.7: 1$ & \\
\hline \multirow{2}{*}{ D3 } & \multirow{2}{*}{20 min every $2 \mathrm{~h}$} & 0 & 59.90 & 69.80 & 43.58 & 1.57 & $27.8: 1$ & \multirow{2}{*}{0.20} \\
\hline & & 9 & 56.35 & 62.45 & 36.31 & 1.80 & $20.2: 1$ & \\
\hline \multirow{2}{*}{ D4 } & \multirow{2}{*}{20 min every $3 \mathrm{~h}$} & 0 & 59.90 & 69.80 & 43.58 & 1.57 & $27.8: 1$ & \multirow{2}{*}{0.16} \\
\hline & & 9 & 55.97 & 64.09 & 37.26 & 1.92 & 19.4:1 & \\
\hline
\end{tabular}

\subsection{Moisture Contents (MC)}

Achieving the optimum moisture content $(M C)$ of the compost mixture is essential for the microbial decomposition of organic waste. In the beginning, the $M C$ of the composted material was approximately $60 \%$ in all treatments (D1-D4), which is recommended as the optimal range of microbial activity [27,33]. $M C$ remained between approximately $60 \%$ and $53 \%$ during the composting period ( 9 days) in the four treatments (D1-D4) (see Table 3), indicating that $M C$ was not a determining or limiting factor affecting the composting process. In general, the favored $M C$ in the aerobic composting process is around $40 \%-60 \%$, and an initial $M C$ of $60 \%$ is convenient for acceptable and effective composting. However, excessive moisture content $(M C>60 \%)$ leads to low levels of oxygen in the voids between the solid particles of compost, resulting in anaerobic composting conditions. Anaerobic conditions decrease the degradation rate of organic matter, as well as developing bad odors owing to the release of volatile compounds such as hydrogen sulfphide.

\subsection{Carbon to Nitrogen Ratio (C/N)}

The carbon to nitrogen $(C / N)$ ratio is commonly used to describe the organic waste decomposition, and the compost quality with respect to the organic matter and nitrogen cycling. Several studies have found that an initial $C / N$ ratio in the range between 20:1 and 40:1 is optimal for effective composting $[27,32,34]$. When nitrogen is low (corresponding to $C / N$ ratios $>40: 1$ ), the microorganisms take a longer time to break down waste, consequently reducing the composting performance. On the other hand, high nitrogen (low $C / N$ ratios) may cause ammonium toxicity. $C / N$ ratios in the four bioreactors (D1-D4) were about 28:1 on day 0 and decreased to 18.7-20.5:1 on day 9 (Table 3), indicating 
that $N$ was not the determining factor that affects the composting process. The reduction in the $C / N$ ratio during the composting process is attributed mainly to the transformation of carbon to $\mathrm{CO}_{2}$ followed by a lower reduction in the concentration of organic acids, and an increase in the nitrogen content per unit mass of compost material $[33,34]$.

\section{Conclusions}

Four operation methods were suggested and evaluated for composting palm tree residues mixed with chicken manure $(1: 0.75 w / w)$ in rotary bioreactors. The proposed methods were continuous aeration-rotation (D1), aeration-rotation for 20-min every $1 \mathrm{~h}$ (D2), $2 \mathrm{~h}$ (D3), and $3 \mathrm{~h}$ (D4). Among the four operation methods, D2 was found to be the most effective method for composting the palm tree residues-chicken manure mixture. In the D2 method, the compost temperature of $50-57^{\circ} \mathrm{C}$ lasted for $61 \mathrm{~h}$, which is long enough to kill pathogens and weed seeds. In addition, the organic matter degradation $(O M D)$ of the $\mathrm{D} 2$ method was also the highest of the four methods. Nitrogen and $M C$ did not affect the bioreactor performance as well as the composting process because both the $C / N$ ratio and $M C$ were in favorable ranges during the composting time. The D2 method reduces the electric energy consumption to one-third of that consumed by the continuous aeration-rotation method (D1). Composting palm tree residues in a closed system, instead of the traditional utilization method (i.e., burning residues), can help farmers to dispose of these residues in a useful and environmentally friendly way. Thus, serious air-pollution and health problems will be avoided. For energy saving purposes, further research is needed to replace the mechanical aeration with natural aeration; this can be accomplished by making small holes distributed in the bioreactor walls.

Author Contributions: Conceptualization, F.A. and A.M.A.-G.; methodology, A.A.-F.; formal analysis, I.A.-H. and F.A.; investigation, F.A. and I.A.-H.; resources, R.F. and M.I.; data curation, R.F. and M.I.; writing-original draft preparation, F.A. and A.A.-F.; writing—review and editing, A.M.A.-G.; visualization, R.F. and M.I.; supervision, A.M.A.-G. All authors have read and agreed to the published version of the manuscript.

Funding: This research received no external funding.

Acknowledgments: The authors would like to extend their sincere appreciation to the Deanship of Scientific Research at King Saud University for its funding of this research through the research group no. RG-1435-074.

Conflicts of Interest: The authors declare no conflict of interest.

\section{Nomenclature}

$\begin{array}{ll}\mathrm{C} & \text { Carbon content }(\%) \\ \mathrm{C} / \mathrm{N} & \text { Carbon to nitrogen ratio }(-) \\ \mathrm{D} 1-\mathrm{D} 4 & \text { Bioreactor treatments } \\ \mathrm{Dw} & \text { Dry weight }(\mathrm{kg}) \\ L & \text { Liter } \\ \mathrm{h} & \text { Hour } \\ M C & \text { Moisture content }(\%) \\ N C & \text { Nitrogen content }(\%) \\ \text { OM } & \text { Organic matter content }(\%) \\ O M D & \text { Organic matter degradation }(-) \\ Q & \text { Mass }(\mathrm{kg}) \\ T_{\mathrm{am}} & \text { Temperature of the ambient air }\left({ }^{\circ} \mathrm{C}\right) \\ T_{\mathrm{c}} & \text { Temperature of compost }\left({ }^{\circ} \mathrm{C}\right) \\ T_{\mathrm{c}, \max } & \text { Maximum temperature of compost }\left({ }^{\circ} \mathrm{C}\right) \\ T N & \text { Total nitrogen content }(\%) \\ T O C & \text { Total organic carbon }(\%) \\ w & \text { Weight (Newton) }\end{array}$




\section{References}

1. Makkawi, Y.; El Sayed, Y.; Salih, M.; Nancarrow, P.; Banks, S.; Bridgwater, T. Fast pyrolysis of date palm (Phoenix dactylifera) waste in a bubbling fluidized bed reactor. Renew Energy 2019, 143, 719-730. [CrossRef]

2. Agriculture Statistical Annual Book (ASAB-2016). Ministry of Environment, Water and Agriculture, General Authority for Statistics. Available online: https://www.stats.gov.sa/en (accessed on 4 July 2018).

3. El-Juhany, L.I. Surveying of Lignocellulosic Agricultural Residues in Some Major Cities of Saudi Arabia. Available online: https://s3.amazonaws.com/academia.edu.documents/30429135/p100.pdf?response-contentdisposition=inline $\% 3 \mathrm{~B} \% 20$ filename\%3DSurveying_of_lignocellulosic_agricultura.pdf\&X-Amz-Algorithm= AWS4-HMAC-SHA256\&X-Amz-Credential=AKIAIWOWYYGZ2Y53UL3A\%2F20191224\%2Fus-east-1\% 2Fs3\%2Faws4_request\&X-Amz-Date=20191224T023300Z\&X-Amz-Expires=3600\&X-Amz-SignedHeaders= host\&X-Amz-Signature=5cc5da1e3552c8d950a192db90431f84fbdfd9d94b20102c7fdac2cf320bc0b8 (accessed on 24 December 2019).

4. Ismail, Z.Z. Kinetic study for phosphate removal from water by recycled date-palm wastes as agricultural by-products. Int. J. Environ. Stud. 2012, 69, 135-149. [CrossRef]

5. Nasser, R.A.; Salem, M.Z.M.; Hiziroglu, S.; Al-Mefarrej, H.A.; Mohareb, A.S.; Alam, M.; Aref, I.M. Chemical analysis of different parts of date palm (Phoenix dactylifera L.) using ultimate, proximate and thermos-gravimetric techniques for energy production. Energies 2016, 9, 374. [CrossRef]

6. Bulan, R.; Mandang, T.; Hermawan, W.; Desrial. Physical and mechanical properties of palm frond for the development of palm oil waste chopper and pressing machine design. Int. J. Sci. Eng. Res. 2015, 6, 2229-5518.

7. Rasat, M.S.M.; Wahab, R.; Sulsiman, O.; Moktar, J.; Mohamed, A.; Tamer, A.; Khalid, I. Properties of composite boards from oil palm frond agricultural waste. Bioresources 2011, 6, 4389-4403.

8. Perez-Murcia, M.D.; Moreno-Caselles, J.; Moral, R.; Perez-Espinosa, A.; Paredes, C.; Rufete, B. Use of composted sewage sludge as horticultural growth media: Effects on germination and trace element extraction. Comm. Soil Sci. Plant Anal. 2005, 36, 571-582. [CrossRef]

9. Jindo, K.; Suto, K.; Matsumoto, K.; Garcia, C.; Sonoki, T.; Sancchez-Monedero, M.A. Chemical and biochemical characterization of biochar-blended composts prepared from poultry manure. Bioresour. Technol. 2012, 110, 396-404. [CrossRef]

10. Alkoaik, F.N.; Khalil, A.I.; Al-Mahasneh, M.A.; Fulleros, R.B.; El-Waziry, A.M. Changes in color and germination index as indicators for compost maturity. J. Pure App. Microbiol. 2014, 8, 409-417.

11. Alkoaik, F.N. Integrating aeration and rotation processes to accelerate composting of agricultural residues. PLoS ONE 2019, 14, e0220343. [CrossRef]

12. El-Nesr, M.; Alazba, A.; Abu-Zreig, M. Analysis of evapotranspiration variability and trends in the Arabian Peninsula. Am. J. Environ. Sci. 2010, 6, 535-547. [CrossRef]

13. Ajay, S.K.; Kazmi, A.A. Mixed organic waste composting using rotary drum composter. Int. J. Environ. Waste Manag. 2008, 2, 24-35.

14. Ajay, S.K.; Kazmi, A.A. Effects of turning frequency on compost stability and some chemical characteristics in a rotary drum composter. Chemosphere 2009, 74, 1327-1334.

15. Varma, V.S.; Kalamdhad, A.S. Evaluation of chemical and biological characterization during thermophilic composting of vegetable waste using rotary drum composter. Int. J. Environ. Sci. Technol. 2015, 12, $2015-2024$. [CrossRef]

16. Kalamdhad, A.S.; Pasha, M.; Kazmi, A.A. Stability evaluation of compost by respiration techniques in a rotary drum composter. Resour. Conserv. Recycl. 2008, 52, 829-834. [CrossRef]

17. Kalamdhad, A.S.; Singn, Y.K.; Ali, M.; Khwairakpam, M.; Kazmi, A.A. Rotary drum composting of vegetable waste and tree leaves. Bioresour. Technol. 2009, 100, 6442-6450. [CrossRef]

18. Madan, S.; Bhatia, A.; Rajpal, A.; Kazmi, A.A. Maturity assessment of rotary drum and windrow composts in terms of germination index and enzymatic activities. Int. J. App. Sci. Eng. Res. 2012, 1, 415-426. [CrossRef]

19. Ghaly, A.E.; Alkoaik, F.; Snow, A. Thermal balance of in-vessel composting of tomato plant residues. Can. Biosyst. Eng. 2006, 48, 6.1-6.11.

20. Hwang, E.Y.; Park, J.S.; Kim, J.D.; Namkoong, W. Effect of aeration mode on the composting of diesel-contaminated soil. J. Ind. Chem. 2006, 12, 694-701. 
21. Tajima, K.; Yoshimura, M.; Kato, M.; Tatsuno, J.; Tamaki, K. Enhancement of composting process by the addition of chicken manure and rice bran to tree pruning chips. Jpn. J. Farm Work Res. 2003, 38, 207-2013. [CrossRef]

22. Chen, Z.; Zhang, S.; Wen, Q.; Zheng, J. Effect of aeration rate on composting of penicillin mycelial dreg. J. Environ. Sci. 2015, 37, 172-178. [CrossRef]

23. Rasapoor, M.; Adl, M.; Pourazizi, B. Comparative evaluation of aeration methods for municipal soild waste composting from the perspective of resource management: A practical case study in Tihran. Iran. J. Environ. Manag. 2016, 184, 528-534. [CrossRef] [PubMed]

24. Alkoaik, F.N.; Abdel-Ghany, A.M.; Rashwan, M.A.; Fulleros, R.B.; Ibrahim, M.N. Energy analysis of a rotary drum bioreactor for composting tomato plant residues. Energies 2018, 11, 449. [CrossRef]

25. Gao, M.; Liang, F.; Yub, A.; Li, B.; Yang, L. Evaluation of stability and maturity during forced-aeration composting of chicken manure and sawdust at different C/N ratios. Chemosphere 2010, 78, 614-619. [CrossRef] [PubMed]

26. ASTM International Standard 2016. Available online: https://www.techknowledge.me/files/theme/KC/ASTM/ astm_standards2016.pdf (accessed on 24 December 2019).

27. Haug, R.T. Practical Handbook of Compost Engineering; Lewis Publishers: Boca Raton, FL, USA, 1993.

28. Ganguly, R.K.; Chakraborty, S.K. Assessment of microbial roles in the bioconversion of paper mill sludge through vermicomposting. J. Environ. Health Sci. Eng. 2018, 16, 205-212. [CrossRef] [PubMed]

29. Abdul Kadir, A.; Jamaludin, S.N.; Azhar, N.W. An overview of composting based on variable feedstock material. MATEC Web Conf. 2016, 47, 05016. [CrossRef]

30. Petric, I.; Helic, A.; Avdic, E.A. Evolution of process parameters and determination of kinetics for co-composting of organic fraction of municipal solid waste with poultry manure. Bioresour. Technol. 2012, 117, 107-116. [CrossRef]

31. CCME. Guidelines for Compost Quality. Available online: https://www.ccme.ca/files/Resources/waste/ organics/compostgdlns_1340_e.pdf (accessed on 24 December 2019).

32. Estevez-Schwarz, I.; Seoana-Labandeira, S.; Nunez-Delgado, A.; Lopez-Mosquera, E. Production and characterization of compost made from garden and other waste. Pol. J. Environ. Stud. 2012, 21, 855-864.

33. Cabanas-Vargas, D.D.; Sánchez-Monedero, M.A.; Urpilainen, S.T.; Kamilaki, A.; Stentiford, E.I. Assessing the stability and maturity of compost at large-scale plants. Revista Académica de Ingeniería 2005, 9, 25-30.

34. Tiquia, S.M. Reduction of compost phytotoxicity during the process of decomposition. Chemosphere 2010, 79, 506-512. [CrossRef] 